\title{
PENGARUH PROGRESSIVE MUSCLE RELAXATIONS TERHADAP KUALITAS TIDUR DAN KADAR GLUKOSA DARAH DI DESA HULU KECAMATAN PANCUR BATU KABUPATEN DELI SERDANG
}

\author{
Magda Siringo-ringo ${ }^{1}$, Imelda Sirait $^{2}$, Lindawati Simorangkir ${ }^{3}$ \\ ${ }^{1}$ Program Studi D3 Keperawatan, STIKes Santa Elisabet Medan \\ ${ }^{2,3}$ Program Studi Ners, STIKes Santa Elisabet Medan \\ Email : ${ }^{1}$ magda_siringoringo@yahoo.com, ${ }^{2}$ imeldasirrait16@gmail.com, \\ ${ }^{3}$ lindasimorangkir79@gmail.com
}

\begin{abstract}
ABSTRAK
Diabetes melitus mengakibatkan mekanisme pengontrolan kadar glukosa dalam tubuh relative. Apabila tidak terkontrol, menimbulkan potensial komplikasi yaitu hiperglikemia. Hiperglikemia kondisi dapat ditemukan pada pasien diabetes mengalami kecemasan, strees hebat berkepanjangan dan kurang aktifitas/exercise sehingga berdampak kualitas tidur tidak adekuat, akhirnya menimbulkan meningkatkan kadar glukosa darah setiap sistem tubuh. Tujuan penelitian ini adalah untuk mengidentifikasi pengaruh progressive muscle relaxations terhadap kualitas tidur dan penurunana kadar glukosa darah. Metode pendekatan kuantitatif dan nonquivalent control group design, sampel dalam penelitian berjumlah 32 masyarakat yang mengalami diabetes. Analisis data dengan uji statistik Wilcoxon Sign Range Test dan Mann Whitney U. Hasil penelitian ini menunjukkan adanya pengaruh Progresive Muscle Relaxation dengan peningkatan kualitas tidur yang sangat signifikan dimana perbedaan intervensi pertama (1) pada diabetes $p=0.695(<0.05)$, dan kelompok intervensi kedua (2) $p=0.00(p<0.05)$, dan adanya pengaruh yang sangat signifikan. Progresive Muscle Relaxation terhadap penurunan glukosa darah dengan perbedaan sebelum dan setelah intervensi pertama (1) pada diabetes $p=0.627$ ( $p>0.05$ ), dengan intervensi kelompok kedua (2) diabetes $p=0.00$ ( $p<0.05)$. Hasil penelitian ini menunjukkan bahwa progressive muscle relaxation sangat efektif dalam mempertahankan kadar gula darah dan meningkatkan kualitas tidur penderita diabetes. Estimasi ataupun referensi bagi petugas pelayanan kesehatan agar dapat memberikan terapi non farmakologik pada kasus-kasus diabetes melitus. Saran kepada pasien diabetes upanya selalu aktif melakukanan relaksasi otot progresive (Progresive Muscle Relaxation) secara teratu dan terukur setiap hari, dalam mengurangi ketenganan otot, kecemasan strees menstabilkan kadar glukosa darah serta meningkatkan kualitas tidur dalam pilar mengendalikan komplikasi diabetes.
\end{abstract}

Kata Kunci: Relaksasi Otot Progresif, Kualitas Tidur, Kadar Glukosa Darah, Diabetes.

\section{ABSTRACT}

Diabetes mellitus results in a mechanism for controlling glucose levels in the body relative. If not controlled, it can lead to potential complications, namely hyperglycemia. Hyperglycemia conditions can be found in diabetic patients experiencing anxiety, prolonged severe stress and lack of activity / exercise so that it affects inadequate sleep quality, eventually causing increased blood glucose levels in every body system. The purpose of this study was to identify the effect of progressive muscle relaxations on sleep quality and decrease in blood glucose levels. Methods of quantitative approach and nonquivalent control group design, the sample in this study amounted to 32 people with diabetes. Data analysis with statistical test Wilcoxon Sign Range Test and Mann Whitney $U$. The results of this study indicate the effect of Progressive Muscle Relaxation with a very significant increase in sleep quality where the difference in the first intervention ( 1$)$ in diabetes $p=0.695$ (<0.05), and the intervention group second (2) $p=0.00$ ( $p<0.05)$, and there is a very significant effect. Progressive Muscle Relaxation on decreasing blood glucose with differences before and after the first intervention (1) in diabetes $p=0.627$ ( $p>0.05)$, with the second group intervention (2) diabetes $p=0.00(p<0.05)$ Conclusions; The results of this study indicate that Progressive muscle relaxation is very effective in maintaining blood sugar levels and improving sleep quality for diabetic patients. An estimate or reference for health care workers in order to provide non-pharmacological therapy in cases of erupting diabetes. Suggestions to diabetic patients are to always actively perform progressive muscle relaxation (Progressive Muscle Relaxation) regularly and measurably every day, in reducing muscle tension, stress anxiety, stabilizing blood glucose levels and improving sleep quality in the pillars of controlling diabetes complications.

Keywords: Progressive Muscle Relaxation, Sleep Quality, Blood Glucose Levels, Diabetes. 


\section{PENDAHULUAN}

Diabetes tipe 2 adalah kondisi di mana kadar gula dalam darah melebihi nilai normal. Kadar glukosa darah yang tinggi disebabkan tubuh tidak menggunakan hormon insulin secara normal. Hormon insulinmembantu glukosa masuk ke dalam sel tubuh untuk diubah menjadi energi. Diabetes relative mengakibatkan potensial komplikasi hiperglikemia yang disebabkan kenaikan penurunan insulin atau resisten insulin yang diproduksi pankreasi. Data diabetes di Amerika Serikat berkisar 8,3\% Cina 3,9\%, Indonesia berada menduduki ranking ke 4 terbesar di dunia. Penyandang diabetes melitus pada tahun 2014 berjumlah 387 juta sebanyak $(8,3 \%)$ dan diperkirakan akan meningkat menjadi 592 juta tahun 2035 (International Diabetes Federation (IDF, 2006 dalam Soegondo, et al., 2009).

Data Dinas Kesehatan Kabupaten Deli Serdang Propinsi Sumatera Utara Medan, kunjungan pasien diabetes melitus sebayank 13.459 kunjungan penyait tidak menular diabetes melitus dan hipertensi tahun 2018, sedangkan kunjungan pemeriksaan kesehatan kontrol gula darah ke Puskesmas Pancur Batu terdiagnosis diabetes melitus berkisar $(4,71 \%$.) penyakit tidak menular dengan urutan peringkat kedua.

Glukosa adalah karbohidrat yang paling sederhana diserap ke dalam cairan darah melalui sistem pencernaan. Pengendalian mencegah potensial komplikasi diabetes sangat diperlukan strategi pengelolaan pengontrolan kadar glukosa darah dalam tubuh melaksanakan empat pilar yaitu, edukasi, pola makan, olahraga lexercise/aktifitas fisik dan farmakologik. Pengontrolan kadar glukosa darah dalam tubuh terdapat beberapa teknik yaitu; relaksasi otot progresif (Progresive Muscle Relaxation) nafas dalam, relaksasi autogenik, Benson (Moyad \& Hawks, 2009). Tehnik relaksasi dapat dilakukan dengan gerakan dan instruksi yang lebih sederhana, yaitu dengan posisi berbaring, duduk dikursi dan duduk bersandar yang memungkinkan klien dapat melakukannya dimana saja tanpa menyita banyak waktu adalah relaksasi autogenik (Greenberg, 2012).

Penelitian tentang relaksasi autogenik dapat menurunkan kecemasan dalam masalah tidur dan penurunan kecemasan pada mahasiswa keperawatan (Kanjia, et al.,
2010); Bowden, et. all, 2012), dan menurunkan kadar glukosa darah, tekanan darah pada pasien diabetes melitus dan hipertensi. Relaksasi otot menyeluruh bekerja dengan pengaturan hormon kortisol dan hormon stres lainnya. Menurut (National Safety Council, 2004), posisi berbaring memungkinkan gravitasi untuk mendukung. Posisi duduk memiliki keuntungan lebih praktis, mudah ekonomis, tak membutuhkan perlengkapan secara khusus serta dapat dilakukan kapan, dimana saja.

Berdasarkan latar belakang diatas dalam meningkatnya komplikasi diabetes upaya mengendalikan pengelolaan empat pilar yaitu edukasi, pola makan, olahraga/exercise/aktifitas fisik/pergerakan tubuh dan farmokologik dalam menstabilitasi kadar glukosa darah, maka dalam penelitian tertarik untuk menerapkan pilar olahraga/exercise Progressive muscle relaxation pada diabetes di Desa Hulu Kecamatan Pancur Batu.

\section{METODE}

Penelitian ini menggunakan metode quasi eksperimen pre dan post pada pasien diabetes yang berjumlah 32 penderita diabetes. Sampel yang digunakan dalam penelitian yaitu menggunakan teknik consecutive sampling. Pengumpulan data menggunakan pendekatan observatif intervensi relaxation progressive muscle pada diabetes, menggunakan lembar observasi standar operasional prosedur terdiri dari 15 gerakan yang dilakukan untuk mengamati pelaksanaan Progressive muscle relaxation (PMR) setiap 3 kali dalam 1 minggu yaitu dengan membuat tanda checliks pada kolom "ya: jika teknik Progressive Muscle Relaxation (PMR) responden dengan duduk di kursi, pakaian yang longgar, lingkungan yang aman dan stopwatch.

Pengukuran kadar glukosa darah Pre dan Post Intervensi dilaksanakan dengan menggunakan glukometer data kadar gula darah responden menunjukkan 80-144 mg/dl tergolong nornal, skala $(149-179 \mathrm{mg} / \mathrm{dl})$ sedang dan skala ( $\geq 180 \mathrm{mg} / \mathrm{dl}$ ) kadar glukosa darah dalam keadaan buruk. Pengukuran kualitas tidur Pre dan Post Intervensi dilaksanakan dengan menggunakan sleeping index atau Pittsburgh Sleep Quality Index (PSQI) data diabetes menggunakan skala 1-7 atau $\leq 5$ menyatakan bahwa kualitas tidur 
istirahat penderita diabetes melitus dalam keadaan baik, dan skala ( $\geq 5-21)$ menyatakan kualitas tidur istirahat buruk. Analisis data secara univariat dan bivariat menggunakan uji statistik Wilcoxon Sign Range Test dan Mann Whitney $U$.

\section{HASIL DAN PEMBAHASAN}

\subsection{Hasil}

Tabel 1. Distribusi Karakteristik Diabetes Melitus di Desa Hulu Kecamatan Pancur Batu Kabupaten Deli Serdang

\begin{tabular}{|c|c|c|c|c|}
\hline \multirow[t]{2}{*}{ Karakteristik } & \multicolumn{2}{|c|}{ Kelompok Perlakuan } & \multicolumn{2}{|c|}{ Kelompok Kontrol } \\
\hline & Jumlah (f) & Persentase $(\%)$ & Jumlah (f) & Persentase (\%) \\
\hline \multicolumn{5}{|l|}{ Jenis Kelamin } \\
\hline Laki-Laki & 9 & 28,1 & 12 & 37,5 \\
\hline Perempuan & 23 & 71,9 & 20 & 62,5 \\
\hline Jumlah & 32 & 100,0 & 32,0 & 100,0 \\
\hline \multicolumn{5}{|l|}{ Umur (thn) } \\
\hline$<50$ & 5 & 15.6 & 2 & 6,3 \\
\hline $51-60$ & 16 & 50.0 & 16 & 50,0 \\
\hline$>61$ & 11 & 34.4 & 14 & 43,7 \\
\hline Jumlah & 32,0 & $\mathbf{1 0 0 . 0}$ & 32.0 & 100,0 \\
\hline \multicolumn{5}{|l|}{ Pendidikan } \\
\hline SD & & - & 2 & 6,3 \\
\hline SMP & 12 & 37,5 & 16 & 50,0 \\
\hline SMA & 14 & 43,8 & 14 & 43,7 \\
\hline PT & 6 & 18,8 & - & - \\
\hline Jumlah & 32,0 & 100,0 & 32 & 100,0 \\
\hline \multicolumn{5}{|l|}{ Pekerja } \\
\hline Tak Kerja & - & 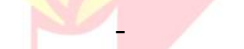 & 7 & 21,9 \\
\hline Buruh & 12 & 37,5 & 14 & 43,7 \\
\hline Wiraswasta & 14 & 43,8 & 1 & 3,1 \\
\hline PNS/Pensiun & 6 & 18,8 & 10 & 21,9 \\
\hline Jumlah & 32,0 & 100,0 & 32,0 & 100,0 \\
\hline \multicolumn{5}{|l|}{ Penghasilan Juta/bln } \\
\hline $1-3$ & 4 & 12,5 & 13 & 40,6 \\
\hline $4-5$ & 10 & 31,3 & 6 & 18,8 \\
\hline$>5$ & 18 & 56,3 & 13 & 40,6 \\
\hline Jumlah & 32,0 & 100,0 & 32,0 & 100,0 \\
\hline \multicolumn{5}{|l|}{ Status } \\
\hline Tidak & 3 & 9,4 & - & - \\
\hline Menikah & 26 & 81,3 & 30 & 93,8 \\
\hline Janda & 3 & 9,4 & 2 & 6,3 \\
\hline Jumlah & 32,0 & 100,0 & 32,0 & 100,0 \\
\hline \multicolumn{5}{|l|}{ Lama } \\
\hline $1-10$ & 19 & 59,7 & 17 & 53,1 \\
\hline $11-20$ & 12 & 37,5 & 15 & 46,9 \\
\hline$>21$ & 1 & 3,1 & & \\
\hline Jumlah & 32,0 & 100.0 & 32,0 & 100,0 \\
\hline
\end{tabular}

Tabel diatas menunjukkan status mayoritas (93\%) menikah kelompok kontrol $(81,3 \%)$. Jenis kelamin perempuan kelompok perlakuan $(71,9 \%)$ sedangkan kontrol sebesar $(62,5 \%)$. Umur antara kelompok perlakuan dan kontrol berkisar 51-60 tahun sebesar (50,0\%), Pendidikan kelompok kontrol lulusan SMP, perlakuan 6 orang perguruan tinggi $(18,8 \%)$, pekerjaan sebagian besar wiraswasta sebesar 14 orang $(43,7 \%)$ baik kelompok perlakuan dan kontrol, dengan demikian dari segi penghasilan sebagian besar lebih lima juta perbulan kelompok perlakuan 18 orang $(56,7 \%)$ dan kontrol 13 orang $(40,6 \%)$, lama menderita penyakit diabetes melitus berkisar 1-10 tahun kelompok perlakuan 19 orang $(59,7 \%)$, kontrol 17 orang $(53,1 \%)$. 
Tabel 2. Distribusi Progressive Muscle Relaxation/PMR Terhadap Kualitas Tidur Diabetes Di

Desa Hulu Kecamatan Pancur Batu Kabupaten Deli Serdang

\begin{tabular}{|c|c|c|c|c|c|c|c|c|}
\hline \multirow[t]{3}{*}{ Kualitas Tidur } & \multicolumn{4}{|c|}{ Kelompok Perlakuan } & \multicolumn{4}{|c|}{ Kelompok Kontrol } \\
\hline & \multicolumn{2}{|c|}{ Pre } & \multicolumn{2}{|c|}{ Post } & \multicolumn{2}{|c|}{ Pre } & \multicolumn{2}{|c|}{ Post Intervensi } \\
\hline & $\mathbf{f}$ & $\%$ & $\mathbf{f}$ & $\%$ & $\mathbf{f}$ & $\%$ & f & $\%$ \\
\hline SB & 0 & 0 & 6 & 18,7 & 4 & 12,6 & 6 & 18,7 \\
\hline $\mathrm{CB}$ & 18 & 56,2 & 26 & 81,3 & 27 & 84,3 & 26 & 81,3 \\
\hline $\mathrm{CB}$ & 14 & 43,8 & & & 1 & 3,1 & & \\
\hline SB & & & & & & & & \\
\hline Jlh & 32 & 100 & 32 & 100 & 32 & 100 & 32 & 100 \\
\hline $\begin{array}{l}\text { Wilcoxon Signed } \\
\text { rank Test }\end{array}$ & \multicolumn{4}{|c|}{$\mathrm{P}=0,000$} & \multicolumn{2}{|c|}{$\mathrm{P}=0,408$} & & \\
\hline Menney Whitnney & \multicolumn{8}{|c|}{$\mathrm{P}=0,000$} \\
\hline
\end{tabular}

Sumber: Data Desa Hulu, 2019

Tabel diatas bahwa perbedaan hasil antara pre-test dan post-test dari setiap masing-masing kelompok. Hasilnya adalah ada peningkatan kualitas tidur yang dapat dilihat dengan uji statistik Wilxocon Signed Rank Test sangat signifikan nilai $\mathrm{p}=0,000$, dengan demikian bahwa dilakukannya tindakan relaksasi otot progresif adanya peningkatan kualitas tidur pada kelompok perlakuan, hal ini ditunjukan dengan nilai $\mathrm{p}=0,000$, sedangkan kelompok kontrol ditemukan ditemukan nilai $\mathrm{p}=0,408$ sehingga tidak terjadi peningkatan kualitas tidur tidak

signifikan. Dari data tersebut diatas pada kelompok perlakuan terjadi peningkatan kualitas tidur pada diabetes sebelum dan sesudah dilakakukanya tindakan latihan progresive otot relaksasi pada diabetes. Hasil uji Mann Whitnney Test dalam mengetahui perbedaan score kualitas tidur antara kelompok perlakuan dan kontrol setelah dilaksanakannya progresive otot relaksasi pada diabetes, hal ini, dapat ditunjukan dengan nilai $\mathrm{p}=0,000$, berarti adanya perbedaan skore paling signifikan antara kelompok kontrol dengan perlakuan.

Tabel 3. Distribusi Progressive Muscle Relaxation/PMR Terhadap Kadar Glukosa Darah Sewaktu Pada Diabetes Di Desa Hulu Kecamatan Pancur Batu Kabupaten Deli Serdang

\begin{tabular}{|c|c|c|c|c|c|c|c|c|}
\hline \multirow{3}{*}{$\begin{array}{c}\text { Kadar Glukosa Darah } \\
\text { Sewaktu }\end{array}$} & \multicolumn{4}{|c|}{ Kelompok Perlakuan } & \multicolumn{4}{|c|}{ Kelompok Kontrol } \\
\hline & \multicolumn{2}{|c|}{ Pre } & \multicolumn{2}{|c|}{ Post } & \multicolumn{2}{|c|}{ Pre } & \multicolumn{2}{|c|}{ Post } \\
\hline & f & $\%$ & f & $\%$ & f & $\%$ & $\mathbf{F}$ & $\%$ \\
\hline Baik & 15 & 46,8 & 10 & 31,2 & 0 & 0 & 2 & 6,2 \\
\hline Sedang & 17 & 53,2 & 22 & 68,8 & 28 & 87,5 & 21 & 65,6 \\
\hline Buruk & - & - & - & - & 4 & 12,5 & 8 & 25 \\
\hline $\mathrm{Jlh}$ & 32 & 100 & 32 & 100 & 32 & 100 & 32 & 100 \\
\hline Wilcoxon Signed rank Test & \multicolumn{4}{|c|}{$\mathrm{P}=0,000$} & \multicolumn{4}{|c|}{$\mathrm{P}=0,695$} \\
\hline Menney Whitnney & & & & & & & & \\
\hline
\end{tabular}

Sumber: Data Desa Hulu, 2019

Tabel diatas menunjukan bahwa mengalami perbedaan hasil antara pre-test dan post-test dari setiap masing-masing kelompok.hasil pre-test dan post-tes perlakuan serta kelompok kontrol menunjukkan terjadi penurunan kadar gula darah sewaktu yang dapat dilihat uji statistik Wilxocon Signed Rank Test signifikan $\mathrm{p}=0,000$, adanya kestabilan penurunan kadar gulukosa darah pada kelompok perlakuan, hal ini ditunjukan dengan nilai $p=0,000$, sedangkan kelompok kontrol dilakukan uji statistik dengan Paired T-test didapatkan $\mathrm{p}=0,679$ sehingga tidak terjadi penurunan kadar glukosa darah sewaktu tidak signifikan dari data tersebut diatas pada kelompok perlakuan terjadi penurunan kadar glukosa darah pada diabetes sebelum dan sesudah dilakakukanya tindakan latihan progresive otot relaksasi pada diabetes. Hasil uji Mann Whitnney Test dalam mengetahui perbedaan score kualitas tidur antara kelompok perlakuan dan kontrol setelah dilaksanakannya progresive otot relaksasi pada diabetes, hal ini, dapat ditunjukan dengan nilai $\mathrm{p}=0.000$ yang berarti adanya perbedaan score paling signifikan antara kelompok kontrol dengan perlakuan. 
Tabel 4. Hasil Kadar Glukosa Darah Sebelum dan Setelah Progresive Otot Relaksasi Pada Diabetes di Desa Hulu Kecamatan Pancur Batu Kabupaten Deli Serdang

\begin{tabular}{|c|c|c|c|c|c|c|c|c|c|}
\hline \multirow{2}{*}{\multicolumn{2}{|c|}{\begin{tabular}{ll}
\multicolumn{2}{c}{ Variabel } \\
Kadar Gula
\end{tabular}}} & & (n) & Statistik & Mean & Median & SD & Min & Max \\
\hline & & Pre & 32 & 136,50 & 274,7 & 138,5 & 155,42 & 114 & 164 \\
\hline $\begin{array}{l}\text { Kadar } \\
\text { Darah I }\end{array}$ & & Post & 32 & & 4 & 150,2 & 155,42 & 114 & 174 \\
\hline \multirow{2}{*}{$\begin{array}{l}\text { Kadar } \\
\text { Darah II }\end{array}$} & \multirow[t]{2}{*}{ Gula } & Pre & 32 & & 274,7 & 138,07 & 15 & 114 & 168 \\
\hline & & Post & 32 & 140,84 & 265,4 & 139,50 & 150,12 & 115 & 174 \\
\hline
\end{tabular}

Sumber: Data Desa Hulu, 2019

Tabel 4 diatas menunjukkan rerata kadar gulukosa darah diabetes sebelum intervensi relaksasi otot progresive kelompok pertama $174,7 \mathrm{mg} / \mathrm{dl}$ dengan stadar deviasi $155,42 \mathrm{mg} / \mathrm{dl}$. Dengan demikian dengan nilai terendah $114 \mathrm{mg} / \mathrm{dl}$ dan nilai tertinggi 174 $\mathrm{mg} / \mathrm{dl}$. Sedangkan nilai rerata intervensi kedua kadar gula darah penurunan kadar glukosa darah sewaktu pada diabetes setelah dilaksanakan relaksasi otot progresive 265,4 $\mathrm{mg} / \mathrm{dl}$ dengan standar deviasi $150,12 \mathrm{mg} / \mathrm{dl}$ tertinggi $174 \mathrm{mg} / \mathrm{dl}$. Sedangkan intervensi yang ketiga terhadap relaksasi otot progresive penurunan kadar darah sewaktu dengan rerata terendah $114 \mathrm{mg} / \mathrm{dl}$ dan nilai tertinggi 174 $\mathrm{mg} / \mathrm{dl}$. Sedangkan intervensi yang ketiga terhadap relaksasi otot. Hasil analisis uji normalitas data kadar glukosa darah sebelum dan setelah relaksasi otot progresive kelompok perlakuan satu dan dua Uji normalitas data dilakukan dengan uji Shapiro dengan nilai terendah $114 \mathrm{mg} / \mathrm{dl}$ dan nilai Wilk.

Tabel 5. Hasil Normalitas Kadar Glukosa Darah Diabetes Sebelum Setelah Relaksasi Otot Progresive di Desa Hulu Kecasmatan Pancur Batu Kabupaten Deli Serdang

\begin{tabular}{lccccc}
\hline \multicolumn{1}{c}{ Kel pk } & Statistik & df & Shapiro-Wilk & Statistik & Kolmogoro-Smirnov \\
\cline { 3 - 6 } & & \multicolumn{3}{c}{ Sig } & \\
\hline Pre 1 & 0.1230 .124 & 32 & .502 & 0.154 & 0.031 \\
\cline { 1 - 4 } Post 1 & & 32 & 592 & 0.152 & 0.032 \\
\hline Pre II & 0.121 & 32 & .402 & 0.238 & 0.00 \\
Post II & 0.135 & 32 & 135 & 0.122 & 0.20 \\
\hline
\end{tabular}

Sumber: Data Desa Hulu, 2019

Tabel 5 diatas menunjukkan dapat bahwa setelah dilakukan uji normalitas Shpiro-Wilk pada kadar glukosa darah sewaktu diabetes pada tahap pertama diperoleh nilai $\mathrm{p}=0,502(\mathrm{p}>0,05)$, berarti kadar glukosa darah diabetes intervensi tahap pertama ini berdistribusi normal. Hal serupa dengan kadar gula darah diabetes setalah intervensi relaksasi otot progresive fase ke dua dengan nilai $p=0,402(p>0,05)$ dan tahap intervensi ketiga $\mathrm{p}=0,135(\mathrm{p}=>0,05)$, dengan analisis kesimpulan uji statistik Shapiro-Wilk berdistibusi normal kadar glukosa darah diabetes uji Kolmogorov-Smirnovhasil intervensi pertama $\mathrm{p}=0,031$, tahap kedua $\mathrm{p}=0,000$ dan tahap ketiga $\mathrm{p}=0,020$. Berarti adanya perbedaan skore paling signifikan antara kelompok perlakuan secara bertahap dengan tindakan relaksasi otot progresive penurunan kadar glukosa darah sewaktu diabetes meletus.

\subsection{Pembahasan}

1. Pengaruh Relaksasi Otot Progresive terhadap Kualitas Tidur Diabetes di Desa Hulu Kecamatan Pancur Batu

Penelitian menunjukkan pengaruh relaksasi otot progresive terhadap kualitas tidur pada diabetes sangat signifikan dengan penerapan, relaksasi otot progresive mengendalikan masalah komplikasi pada diabetes yaitu gangguan tidur (insomnia), dimana teknik latihan mengarah kangerakan mengencangkan dan melemaskan bagian sistem otot tubuh dimana efektifitasnya memberikan perasaan rileks progresive. Gerakan yang mengencangkan melemaskan metode Continous, Intensitas, Durasi, Rhytmical. Frequency Progresif, Endurance (CIDRFEP) durasi 15-30 menit dalam waktu 3 kali perminggu selama sebulan pada diabetes meletus mengalami gangguan tidur diabetes.

Pada saat melaksanakan relaksasi otot progresive prosedur salah satu persiapan yang dibutuhkan adanya kepercayaan, perasaan, 
pikiran yang diarahkan dalam membandingkan bagaimana perasaan yang dialami saat waktu kelompok sistem otot tubuh dikencangkan dilemaskan kondisi tegang (Malassiolis, et.al. 2002, Smiltzer et.al 2013 dalam Nawa dan Kusnanto Utami, 2018). Dalam penelitian ini penderita diabetes ditemukan bahwa rerata kualitas tidur yang sangat buruk yang sering disebut insomnia. Seorang pasien yang tidurnya kurang dapat menyebabkan beberapa gangguan pada respon imun, endokrin dan fungsi kardiovaskuler (Erlina E., Haroen, H., Susanti, RD., 2012 dalam Gay, 2010 \& Caple \& Grose, 2 011).

Hal sama juga penelitian (Purnanto, 2009) rerata pasien diabetes insomia. Sebagai faktor pencetus pemicu kualitas tidur tidak cukup baik bagi penderita diabetes dimana sebagai gejala tanda klasik diabetes salah satu nucturia merupakan kontribusi insiden insomnia pada malam hari, meskipun masih ada faktor pencetus lain yang berhubungan dengan gangguan hormonal seperti peningkatan kosticostiroid dalam tubuh. Sebagian pengidap diabetes mellitus akan mengalami gangguan tidur di malam hari. Dalam penelitian ini menunjukkan rerata kadar gulukosa darah diabetes sebelum intervensi relaksasi otot progresive kelompok pertama $174.7 \mathrm{mg} / \mathrm{dl}$ dengan stadar deviasi $155.42 \mathrm{mg} / \mathrm{dl}$. Dengan demikian dengan nilai terendah $114 \mathrm{mg} / \mathrm{dl}$ dan nilai tertinggi 174 $\mathrm{mg} / \mathrm{dl}$. Sedangkan nilai rerata intervensi kedua kadar gula darah penurunan kadar gula darah sewaktu pada diabetes setelah dilaksanakan relaksasi otot progresive 265.4 $\mathrm{mg} / \mathrm{dl}$ dengan standar deviasi $150.12 \mathrm{mg} / \mathrm{dl}$ dengan nilai terendah $114 \mathrm{mg} / \mathrm{dl}$ dan nilai tertinggi $174 \mathrm{mg} / \mathrm{dl}$, Sedangkan intervensi yang ketiga terhadap relaksasi otot progresive penurunan kadar darah sewaktu dengan rerata terendah $114 \mathrm{mg} / \mathrm{dl}$ dan nilai tertinggi 174 $\mathrm{mg} / \mathrm{dl}$, Sedangkan intervensi yang ketiga terhadap relaksasi otot.

Hal sama dengan penelitian ini bahwa diabetes, ketiga hal tersebut dapat disebabkan oleh kadar gula darah yang terlalu tinggi atau terlalu rendah. Perubahan tidur yang dapat dialami penderita diabetes nucturia, hipoglikemia nokturia, sindrom kaki, kegelisahan/kecemasan, neuropati perifer dan sleep apnea (Surani,et, al, 2015). Yang dikaitkan dengan penelitian ini bahwa hasil kadar gula darah terendah kelompok intervensi akhir pemeriksaan menunjukkan terendah $114 \mathrm{mg} / \mathrm{dl}$. Sedangkan dalam penelitian ini, dengan wawancara pada responden bahwa kualitas tidur terganggu dampaknya dalam pelaksanaan relaksasi otot yang akan dilaksanakan pagi sore dengan pendampingan tim peneliti pikiran, kecemasan. Faktor penyebab kualitas tidur antara lain strees, kecemasan, kondisi fisik dan gaya hidup. Hal ini sesuai dengan penelitian yang dilakukan (Sohat, 2014). Hal serupa penelitian sebagai faktor kualitas tidur penderita diabetes salah satu faktor psikologis, gangguan medis umum, gaya hidup, faktor lingkungan fisik dan faktor lingkungan sosial.

Dari hasil wawancara reponden juga mengatakan bahwa mereka sulit memulai tidur dan sering terbangun dimalam hari dan sulit untuk tidur kembali, meskipun tertidur kembali harus menunggu beberapa menit atau beberapa jam. Pada penderita diabetes juga terjadi perubahan pada irama sirkardian tidur normal yaitu penurunan kualitas tidur dikarenakan adanya efek dari terapi relaksasi otot progresif. Hal tersebut sesuai dengan teori (Ramdhani, 2006) dalam Triyanto, 2014) bahwa teknik relaksasi semakin sering dilakukan terbukti efektif mengurangi ketegangan, depressi, strees, kecemasan dengan intervensi pada kualitas tidur yang menurun pada penderita diabetes. Hal itu juga sesuai dengan teori yang dikemukakan oleh (Greenberg, 2002) yang dikutip Mashudi, 2012) mengatakan relaksasi otot-otot progresive akan memberikan hasil setelah dilakukan sebanyak dua kali setiap hari pagi sore secara terus menerus dan teratur Latihan mandiri berkelompok menunjukkan efektifitas yang tinggi bukan sementara saja harus berlangsung selama siklus kehidupan.

(Soewondo, 2012) menyebutkan relaksasi otot progresive rangka menjemen pengelolaan dalam intervensi terhadap penderita diabetes yang mengalami gejala strees, kecemasan ketegangan kualitas tidur kurang sangat buruk (Bernstein, Borkovek \& Hazlett-Stevens, 2000) dalam (Soewondo. 2012) mengemukakan bahwa latihan relaksasi otot progresive terutama adalah untuk penderita diabetes yang mengalami ketegangan otot tinggi. Merupakan indikasi absolut pada diabetes tingkat ketegangan tinggi yang berdampak mengganggu kinerja dan perilaku lain dampak kualitas tidur 
sangat buruk yang disebabkan ketegangan otot dan pikiran kacau. Menurut (Davis, 2010) dalam Purwaningtyas \& Pratiwi (2010) mengemukakan dimana latihan relaksasi progresif teknik terbukti program terapi ketegangan otot mampu mengatasi keluhan ansietas, insomnia, kelelahan, kram otot, nyeri leher dan pinggang, tekanan darah tinggi, fobi ringan dan gagap.

\section{Pengaruh Relaksasi Otot Progresive terhadap Kadar Glukosa Darah Pada Diabetes di Desa Hulu Kecamatan Pancur Batu}

Kadar glukosa darah merupakan sejumlah glukosa terdapat pada plasma darah (Dorlan, 2010). Pemantauan kadar glukosa darah secara primer dibutuhkan dalam menentukan diagnosis penyakit diabetes melitus, hasil pemeriksaan kadar glukosa darah sewaktu > $200 \mathrm{mg} / \mathrm{dl}$ sedangkan kadar glukosa darah puasa $>126 \mathrm{mg} / \mathrm{dl}$ (Waspadji, 2013). Konsumsi karbohidrat terlalu banyak terutama makanan yang mengandung karbohidrat sederhana dapat meningkatkan kadar glukosa dalam darah. Kadar gula darah responden sebelum dan sesudah relaksasi otot progresif. Hasil penelitian ini diketahui bahwa kadar gula darah sebelum latihan relaksasi otot progresif didapatkan nilai ratarata $274,7 \mathrm{mg} / \mathrm{dL}$, dan sesudah melakukan relaksasi otot progresif didapatkan penurunan kadar gula darah dengan nilai rata-rata sebesar $265.4 \mathrm{mg} / \mathrm{dl}$.

Menurut (Junaidin, dalam Ayu Henny, 2018) di Puskesmas Woha mendapatkan perbedaan rata-rata yang signifikan sebelum dan setelah dilakukan latihan relaksasi otot progresif. Rata-rata kadar gula darah sebelum latihan $238,40 \mathrm{mg} / \mathrm{dl}$ dan rata-rata setelah latihan mengalami penurunan menjadi 125,68 $\mathrm{mg} / \mathrm{dl}$ dengan demikian ada penurunan kadar gula darah setelah dlaksanakan relaksasi otot progresif hal ini sebagai efektif terhadap tubuh rileks. Sistem parasimpatis merangsang hipotalamus menurunkan sekresi corticotrophin releasing hormone (CRH). Penurunan $\mathrm{CRH}$ akan mempengaruhi sekresi adreno corticotropik hormone (ACTH). Keadaan ini dapat menghambat korteks adrenal untuk melepaskan hormon kortisol penurunan/menghambat proses gluconeogenesis sehingga meningkatkan pemakaian glukosa oleh sel, sehingga kadar gula darah kembali dalam batas normal. Ada pengaruh yang signifikan Progressive Muscle Relaxation terhadap kadar glukosa darah pada pasien. Penelitian ini juga menunjukkan adanya penurunan kadar gula darah diabetes sebelum setelah intervensi rerata intervensi pertama $274,7 \mathrm{mg} / \mathrm{dl}$ setelah intervensi 165,4 $\mathrm{mg} / \mathrm{dl}$. Perbedaannya skore antara sebelum setelah kolompok intervensi membandingkan relaksasi otot progresive dengan kelompok kontrol.

Dari hasil penelitian (Mashudi, 2011) jelas bahwa relaksasi otot progresive dapat menurunkan kadar glukosa darah diabetes dengan memunculkan kondisi rileks. Pada kondisi ini terjadi perubahan impuls saraf pada jalur aferen ke otak dimana aktivasi manjadi inhibisi. (Yildirim \& Fadiloglu, 2016) dari hasil penelitiannya menyebutkan bahwa relaksasi otot progresive menurunkan kecemasan dan meningkatkan kualitas hidup pada diabetes yang menjalani dialisis. Penelitian yang dilakukan oleh (Sheu, et al, 2013) memperlihatkan bahwa PMR menurunkan rata-rata tekanan darah sistolik dan diastolik pada pasien hipertensi di Taiwan. Penelitian (Maryani, 2008), menyebutkan relaksasi otot progresive mengurangi kecemasan yang berimplikasi pada penurunan mual dan muntah pada pasien yang menjalani kemoterapi. Haryati (2009), menyebutkan bahwa relaksasi otot progresive meningkatkan status fungsional pasien kanker dengan kemoterapi di RS. Dr Wahidin Sudirohusodo. Selanjutnya relaksasi otot progresif efektif menurunkan tekanan darah pada pasien hipertensi primer di Kota Malang (Hamarno, 2010). Dalam penelitian ini responden melaporkan bahwa pada saat melakukan relaksasi otot progresive ada dua sensasi yang berbeda yaitu merasakan ketegangan otot ketika bagian otot-otot tubuhnya ditegangkan dan merasakan sesuatu yang rileks, nyaman, enak, dan santai ketika otot-otot tubuh yang sebelumnya ditegangkan tersebut direlaksasikan.

Menurut penelitian (Setyoadi, 2011) teknik relaksasi otot progresif merupakan teknik relaksasi otot tidak memerlukan imajinasi, kekuatan, atau sugesti dan harus berdasarkan keyakinan bahwa tubuh manusia adanya warning kecemasan kejadian yang dirangsang pikiran menimbulkan ketegangan otot. Teknik relaksasi otot progresif memusatkan perhatian terhadap aktivitas otot dalam melakukan teknik relaksasi untuk 
mendapatkan perasaan relaks. Menurut (Sucipto, 2014) relaksasi otot progresif mengarahkan perhatian penderita diabetes dapat membedakan perasaan dialami saat kelompok otot dilemaskan. Relaksasi otot progresif ini mengarahkan perhatian pasien untuk membedakan perasaan yang dialami saat kelompok otot dilemaskan dan dibandingkan dengan ketika otot dalam kondisi tenang, relaksasi otot progresif bermanfaat untuk menurunkan resistensi perifer dan menaikkan elastisitas pembuluh darah. Maka ada pengaruh signifikan Progressive Muscle Relaxation (PMR) terhadap kadar glukosa darah pada pasien diabetes.

Relaksasi otot progresif, sebagai pilar pengelolaan nonfarmakologik yang dapat diberikan kepada pasien diabetes untuk meningkatkan relaksasi dan kemampuan pengelolaan diri. Dimana mekanisme Relaksasi otot progresif dalam menurunkan nilai kadar gula darah pada pasien diabetesi erat kaitannya potensial komplikasi stres yang dialami pasien baik fisik maupun psikologis. Selama stres, hormone-hormon mengarah pada peningkatan kadar gula darah seperti epineprin, kortisol, glukagon, ACTH, kortikosteroid, tiroid akan meningkat. Selain itu dampak beberapa peristiwa kehidupan yang penuh stres sehingga akan mengganggu kualitas tidur dan juga dikaitkan perawatan diri yang buruk seperti pola makan, latihan dan penggunaan obat-obatan (Smeltzer \& Bare, 2008; Price \& Wilson, 2010). Stres fisik maupun emosional mengaktifkan sistem neuroendokrin dan sistem saraf simpatis melalui hipotalamus pituitari-adrenal (Price \& Wilson, 2006; Smeltzer, 2002; DiNardo, 2009).

Perbedaannya dengan penelitian ini adalah, pada penelitian tersebut peneliti membandingkan relaksasi otot progresif dengan kelompok kontrol pada pasien diabetes untuk mengukur kadar gula darah, 64 sampel dibagi dalam dua kelompok, kelompok intervensi diberikan latihan relaksasi otot progresif oleh peneliti selama dua kali sehari pagi sore selama selama 3 minggu selama 15 meit. Hasilnya kelompok intervensi relaksasi otot progresif menunjukkan penurunan kadar gula darah secara signifikan minggu pertama dan kedua nilai $(\mathrm{p}=0,001)$, sedangkan kelompok kontrol kadar gula darah nilai $(\mathrm{p}=0,507)$. Hipofisis anterior juga diinhibisi sehingga ACTH yang menyebabkan sekresi kortisol menurun sehingga proses glukoneogenesis, katabolisme protein dan lemak yang berperan meningkat kadar gula darah menurun (Sudoyo, et al, 2006).

Beberapa penelitian mengenai terapie Relaksasi otot progresif/PMR, menunjukkan bahwa manfaat dalam mengatasi masalah kesehatan antara lain; mengurangi ansietas atau kecemasan dan berkurangnya kecemasan ini akan mempengaruhi berbagai macam gejala psikologis dan kondisi medis. Menurut (Yildirim \& Fadiloglu, 2006) bahwa hasil penelitiannya menyebutkan dimana terapi relaksasi otot progresif/PMR menurunkan kecemasan dan meningkatkan kualitas hidup pasien yang menjalani dialisis. Penelitian yang dilakukan (Ardia Putra, 2014) memperlihatkan relaksasi otot progresif PMR menurunkan rata-rata tekanan darah sistolik dan diastolik pada pasien hipertensi di Taiwan. (Maryani, 2008), menyebutkan relaksasi otot progresif mengurangi kecemasan yang berimplikasi pada penurunan mual dan muntah pada pasien yang menjalani kemoterapi. (Haryati, 2009), menyebutkan bahwa relaksasi otot progresif meningkatkan status fungsional pasien kanker dengan kemoterapi di RS. Dr Wahidin Sudirohusodo.

Selanjutnya relaksasi otot progresif efektif menurunkan tekanan darah pada pasien hipertensi primer di Kota Malang (Hamarno, 2010). Dalam penelitian ini responden melaporkan bahwa pada saat melakukan relaksasi otot progresif /PMR ada dua sensasi yang berbeda yaitu merasakan ketegangan otot ketika bagian otot-otot tubuhnya diteganggkan dan merasakan sesuatu yang rileks, nyaman, enak dan santai ketika otot-otot tubuh yang sebelumnya ditegangkan tersebut direlaksasikan. Kemungkinan lain adalah kemampuan responden melaksanakan relaksasi otot progresif dengan tepat benar. Meskipun responden dapat melakukan semua prosedur atau langkah-langkah relaksasi otot progresif namun bila yang bersangkutan tidak mampu memusatkan pikiran dalam melaksanakan relaksasi otot progresif menimbulkan efektifitas kurang membawa hasil yang maksimal, karena relaksasi otot progresif merupakan salah satu bentuk mind-body therapy. Pengaruh relaksasi otot progresive 
Jacobson terhadap kadar gula darah diabetes kelompok intervensi.

Hasil penelitian ditemukan bahwa ratarata kadar gula darah penderita diabetes sebelum dilakukan relaksasi otot progresive 274,.7mg/dl dan setelah dilakukan Progresive Mucsle Relaxation menjadi nilai kadar gula darah sebesar 165,7 mg/dl. Dengan demikian bahwa terdapat rata-rata penurunankadar gula darah berkisar antara 43,50 mg/dl. Analisis selanjutnya dengan menggunakan uji Paired $T$-test diperoleh nilai $\mathrm{p}=, 0.003$ yang artinya ada perbedaan secara signifikan antara kadar gula darah diabetes sebelum dan setelah dilaksanakan Progressive Muscle Relaxation. Pengaruh Progressive Muscle Relaxation terhadap terdapat penurunan kadar gula darah yaitu terjadi saat otot-otot bagian tubuh sedang aktif walau kebutuhan otot akan glukosa meningkat, tetapi tidak disertai peningkatan insuline, ini dapat disebabkan dimana meningkatnya osmolaritas reseptor insuline di otot dan akan bertambahnya volume junlah reseptor insuline aktif waktu melakukan aktifitas fisik, latihan/olahraga, dimana saat waktu beraktifitas fisik/latihan gerakan-gerakan otot bagian tubuh blood flow (BFP) reaktif meningkat ini disebabkan dimana lebih banyak kapiler-kapiler pembuluh darah terbuka sehingga lebih banyak reseptor insuline yang tersedia aktif hal inilah yang berpengaruhi penurunan kadar glukosa darah pada penderita diabetes.

Hal ini disebabkan menurut penelitian (Ocbrivianita, et al, 2012) yang menyatakan bahwa Progresive Mucsle Relaxation yang dilakukan penderita diabetes lebih efektif dalam penurunan kadar glukosa darah, dan penelitian (Wati Widia, 2012) menyebutkan adanya pengaruh Progresive Mucsle Relaxation terhadap penurunan kadar glukosa darah dimana permiabilitas membrane terhadap glukosa meningkat dengan berkontraksinya otot-otot pada saat aktifitas fisik berolahraga secara resistensi insuline meningkat, hal ini akan menyebabkan insuline pada penderita diabetes berkurang, reaksi hanya terjadi jika setiap kali berolahraga/beraktifitas fisik dengan gerakangerakan bagian tubuh, tidak merupakan efek yang permanen atau berlangsung lama, oleh karena itu bahwa beraktifitas fisik/latihan jasmani harus dilaksanakan secara intermitten dan teratur (Ilyas, 2013). Pengaruh terapi Progresive Mucsle Relaxation terhadap kadar glukosa darah pada kelompok perlakuan fase minggu 2 menggunakan uji Paired-T-test $\mathrm{p}=0.000 \quad(\mathrm{p}<0.05) \quad$ adanya perbedaan signifikan. Menurut (Smeltzer \& Bare, 2008 Sherwood, 2014) menyatakan bahwa mekanisme Progresive Mucsle Relaxation dapat menurunkan kadar glukosa darah erat kaitannya kualitas tidur dan istirahat yang dialami diabetes. Selama penderita diabetes mengalami insomnia hormon-hormon yang menimbulkan pada peningkatan kadar glukosa darah seperti epineprin kortisol, glukogan, ACTH kortikosteroid semuanya hal ini akan meningkatkan konversi asam amino, laktat dan piruvat hati menjadi glukosa melalui proses glukoneogenesis, dengan demikian akan terjadi insomnia,dan strees akan meningkatkan glukosa darah (Smeltzer \& Bare, 2008).

Sistem saraf simpatis dan meningkatan akan membutuhkan energe, akan memicu sirkulasi darah ke otot-otot muscle skeletal, meningkatkan detak jantung dan kadar glukosa (Sherwood, 2013). Kortisol memecahkan simpanan lemak, protein yang berbarengan memperbanyak simpanan karbohidrat dan meningkatkan penyediaan glukosa darah, akan terjadi peningkatan cadangan glukosa darah, asam amina (AA) asam lemak dipergunakan dalam kebutuhan tubuh (Sherwood, 2013). Sistem saraf simpatis dan epinefrine disekresikan keduanya memblokir insuline dan menstimulasi glukagon, perubahan hormon ini bersamaan dalam meningkatkan kadar glukosa, asam lemak. Epinefrine dan glokagon kadarnya dalam darah yang meningkat saat insommnia kualitas tidur istirahat tidak terjaga akan mendorong glikogenolisis hati dan kortisol, glukogenolisis hati, bahwa insuline sekresinya tertekan saat kualitas tidur tidak terjaga dalam menghambat pemecahan simpanan glikogen hati. Semua efek akan membantu meningkatkan konsentrasi glukosa darah (Sherwood, 2013).

\section{KESIMPULAN}

Adapun kesimpulan yang dapat diambil yaitu:

1. Ada perbedaan yang sangat signifikan antara kualitas tidur diabetes pada intervensi pertama dengan $\mathrm{p}=0.695$ (p>0.05) dan kelompok intervensi kedua 
terjadi peningkatan kualitas tidur diabetes sangat signifikan $\mathrm{p}=0.00(\mathrm{p}=<0.05) 2$.

2. Ada pengaruh perbedaan yang sangat signifikan antara kadar glukosa darah diabetes sebelum dan setelah intervensi relaksasi otot progresive pada kelompok dengan $\mathrm{p}=0.627 \quad(\mathrm{p}>0.05) \quad$ dengan perbedaan yang signifikan antara kadar glukosa darah diabetes sebelum dan setelah relaksasi otot progresive kelompok intervensi II $\mathrm{p}=0.000(\mathrm{p}<0.05)$.

\section{SARAN}

Kepada pasien diabetes upayakan selalu aktif melakukanan relaksasi otot progresive (Progressive Muscle Relaxation), secara teratur tepat terukur setiap hari, dalam mengurangi ketenganan otot, kecemasan strees dan menstabilkan kadar glukosa darah serta meningkatkan kualitas tidur, oleh karena metode relaksasi otot progresive sederhana, mudah, ekonomis tidak membutuhkan ruangan khusus dan tutorial, namun kemauan optimisme klien diabetes hidup sehat bahagia masa depan, tetap patuh kontrol gula darah sewaktu imbangi diet sehat seimbang sebagai pilar mengendalikan komplikasi diabetes.

\section{REFERENCES}

ADA. (2019). American Diabetes Association Standards of Medical Care In Diabetes-2019 Guidelines Update. 44.

https://www.piedmont.org/media/file/PA R-CME-Diabetes-Blair-ADA-Update2019.pdf

Ayu Henny. 2015 dengan judul "Pengaruh Progressive Muscle Relaxation Dan Senam Diabetes Terhadap Gula Darah Penderita DM Tipe 2 di Wilayah kerja Puskesmas

Bali.http://iosrjournals.org/iosrjdms/papers/Vol13issue2/Version1/H013212528.pdf. diakses tanggal 10 November 2019

Buysse, D. J., Reynolds, C. F., Monk, T. H., Berman, S. R., \& Kupfer, D. J. (1989). PSQI - Escala Avaliação Sono. In Psychiatry Research: Vol. 28(2) (Issue 28, pp. 193-213). https://www.psychiatry.pitt.edu/sites/def ault/files/inline-files/PSQI Article.pdf

Dahlan, S. 2010. Besar Sampel dan Cara Pengambilan Sampel dalam Penelitian
Kedokteran dan Kesehatan. Edisi 3. Jakarta : Salemba Medika.

Davis. (2010). Panduan Relaksasi dan Reduksi Stres Edisi III. Jakarta.

Erliana, E., Haroen, H., \& Susanti, R. D. (2008). Perbedaan tingkat insomnia lansia sebelum dan sesudah latihan relaksasi otot progresif (progressive muscle relaxation) di BPSTW Ciparay Bandung. Perbedaan Tingkat Insomnia Lansia Sebelum Dan Sesudah Latihan Relaksasi Otot Progresif (Progressive Muscle Relaxation) Di BPSTW Ciparay Bandung, pustaka.unpad.ac.id/wp.../07/perbedaan_ tingkat_insomnia_lansia.pdf

Ernawati, Syauqy, A., \& Haisah, S. (2017). Gambaran Kualitas Tidur dan Gangguan Tidur Pada Lansia di Panti Sosial Tresna Werdha Budi Luhur Kota Jambi. 2(disitasi 2019 Maret 6), 5. http://repository.unja.ac.id/2381/1/JURN AL.pdf

Federation, I. D. (2013). Sixth edition.

Guyton dan Hall. 2008. Aktivitas Otak Tidur,Gelombang Otak, Epilepsi, Psikosis.Buku Ajar Fisiologi Kedokteran. EGC. Jakarta. Hal 777

Hamarno, Rudi. (2006). Pengaruh Latihan Relaksasi Otot Progresif Terhadap Penurunan Tekanan Darah Klien Hipertensi Primer Di Kota Malang. (Tesis). Perpustakaan FKUI..

Handayani. (2012). Modifikasi gaya hidup dan intervensi farmakologis dini untuk pencegahan penyakit diabetes mellitus tipe II. Media Gizi Masyarakat Indonesia Vol.1, 65-70.

Hasaini, A. (2015). Efektifitas progressive muscles relaxation (PMR) terhadap kadar gula darah pada kelompok penderita diabetes mellitus Tipe II di Puskesmas Martapura. Caring Vol. 2, No. 1, 16-27.

Hijriana, I., Suza, D. E., \& Ariani, Y. (2016). Pengaruh latihan pergerakan sendi ekstremitas bawah terhadap nilai Ankle Brachial Index (ABI) pada Pasien DM Tipe 2. Idea Nursing journal Vol. VII, No. 2, 32-39. Hoe, J., Koh, W., Jin, A., Sum, C., Lim, S., \& Tavintharan, S. (2012).

Hilman, A. (2017). Progressive Muscle Relaxation. The SAGE Encyclopedia of Abnormal and Clinical Psychology. 
https://doi.org/10.4135/9781483365817. n1072

Ilyas. 2009. Olahraga pasien Diabetes. Agromedia Pustaka: Jakarta.

Indrawati, L. (2018). Pengaruh Relaksasi Otot Progresif terhadap Insomnia pada Lansia di PSTW Budhi Dharma Bekasi 2014. Jurnal Ilmu Kesehatan, 6(2), 140. https://doi.org/10.32831/jik.v6i2.168

Kementrian Kesehatan, RI. (2010). Petunjuk Teknis Pengukuran Faktor Risiko Diabetes Mellitus. Jakarta: KEMENKES RI.

http://perpustakaan.kemkes.go.id. Diakses pada tanggal 23 Juni 2019

Mashudi. (2011). Pengaruh Progressive Muscle Relaxation Terhadap Kadar Glukosa Darah Pasien Diabetes Melitus Tipe 2 Di R.S.U.D Raden Mattaher, (tesis). Perpustakaan FIKUI.

Maghfirah, S., Sudiana, I. K., \& Widyawati, I. Y. (2015). Relaksasi otot progresif terhadap stres psikologis dan perilaku perawatan diri pasien diabetes mellitus tipe II. Jurnal Kesehatan Masyarakat Vol. 10, No. 2, 137-146.

PERKENI. (2011). Konsensus pengendalian dan pencegahan diabetes mellitus tipe II di Indonesia. Diperoleh tanggal 04 Oktober 2019, dari: http://www.perkeni.org

Polit, D. F., \& Beck, C. T. (2014). Essentials of Nursing Research Seventh Edition Appraising Evidence for Nursing Practice. In Lippincott Williams \& Wilkins.Potter Perry. 2010. Fundamental of Nursing. Buku 1 Edisi 7. Jakarta : Salemba Medika.

R, Boedisantoso, A. (2013). Komplikasi Akut Diabetes Melitus dalam Soegondo, S., Soewondo, P., \& Subekti, I. Ed. Penataksanaan Diabetes Melitus Terpadu (hlm 163-185). Jakarta : FKUI.
Rahmadiliyani, N., \& Muhlisin, A. (2008). Komplikasi Pada Penderita Diabetes Melitus Dengan Di Wilayah Kerja Puskesmas I Gatak Sukoharjo. Berita Ilmu Keperawatan, 1(2), 63-68.

Rustam. 2008, Faktor-faktor yang Berhubungan dengan Kadar Gula Darah pada Pasien Diabetes Mellitus di RSU Panglima Sebaya Kabupaten Kalimantan Timur.

Safitrie, A., \& Ardani, M. H. (2013). Studi Komparatif Kualitas Tidur Perawat Shift dan Non Shift di Unit Rawat Inap dan Unit Rawat Jalan. Prosiding Konferensi Nasional PPNI Jawa Tengah, 17-23.

Setiyawati Andina. (2010). Pengaruh Relaksasi Otogenik Terhadap Kadar Gula Darah Dan Tekanan Darah Pada Klien Diabetes Mellitus Tipe 2 Dengan Hipertensi Di Instalasi Rawat Inap Rumah Sakit Di D.I.Y dan Jawa Tengah, (tesis). Perpustakaan FIKUI.

Sherwood, L. (2014). Fisiologi Manusia : Dari Sel Ke Sistem Edisi 8. Jakarta : EGC.

Smeltzer \& Bare. (2008). Textbook of Medical Surgical Nursing Vol.2. Philadelphia: Linppincott William \& Wilkins.

Soegondo, S. (2011). Diagnosis dan Klasifikasi Diabetes Melitus Terkini. Dalam: Soegondo, S.

Soewondo, P. Subekti, I. Editor. Panduan Penatalaksanaan Diabetes Melitus Terpadu bagi Dokter dan Edukator. Jakarta: Balai Penerbit FKUI

Sukardji, 2009 : Penatalaksanaan Diabetes Mellitus Terpadu. Edisi II Cetakan Ke-7. Jakarta: Fakultas Kedokteran UI. Sumadibrata, 2006 : Buku Ajar Ilmu Penyakit Dalam edisi ke IV, Jakarta Fakultas Kedokteran Uiversitas Inndonesia. 